\title{
WORK STRESS AND BURNOUT: EUSTRESS A TOOL TO DEAL
}

\author{
Dr. Manisha Choudhary \\ Associate Professor, Vivekananda Global university, Jaipur, Rajasthan, India \\ Dr. Saroj Kumar Ranjan \\ Assistant Professor, Dr.K.N. Modi University, Newai, Rajasthan, India
}

\begin{abstract}
It is important to know what causes burnout. So, you can address the root of the issue instead of getting bogged down with treating the symptoms. So, ask yourself why this is happening keep a Journal or diary compare, how you used to feel think act at work to how you feel think and act at work now. what is changed, what has happened once you identify the problem ask yourself is a work-related issue or is this a lifestyle or personality issue.

This theoretical research paper tried to show that how work stress and burnout affect the work life balance. Whare as how Eustress changes the thoughts of human behaviour to come over it. Hope, Self Esteem, Locus of control, Desire are the tools that increases the Eustress and decreases the level of burnout and stress.

Key words: Stress Eustress, Job Burnout, Positivity, Optimism, Hope, Self-Esteem, Self-Efficiency and Locus of Control

Cite this Article: Manisha Choudhary and Saroj Kumar Ranjan, Work Stress and Burnout: Eustress A Tool to Deal, International Journal of Management (IJM), 11(12), 2020, pp. 3142-3147.

http://iaeme.com/Home/issue/IJM?Volume=11\&Issue $=12$
\end{abstract}

\section{INTRODUCTION}

It is like you are always stuck in second year when it hasn't been your day your week your month or even year well could be more than just stress. you could be crossing over into burnout what is the difference stress right no burnout is something different. Job stress can be defined as the harmful physical and emotional responses that occur when requirements at the job do not match the capabilities resources or needs of the worker let us take a step further.

when you experience job stress, you can still get things done. you can still produce you just feel like you are not doing enough just because you have a stressful day or week stressful project, or a stressful client does not mean you burnout. you can have job stress and not have job burnout. 
Job burnout is a special type of job stress a state of physical mental or emotional exhaustion combined with doubts about your competence and the value of your work remember. Stress can be characterization overabundance that feeling of too much with burnout. You can expose to this state of stress for so long that you have nothing left. You feel empty motivation is gone, you do not care, you have no hope. You will so have burned out that her job was on the line and you did not care most of us in that situation put a bit embarrassed that we got in trouble would have been scared. We are going to lose our jobs but embarrassed and scared our feelings and burnout brings with it a numbing effect. At a point where you feel nothing.

Burnouts start with stress, there are lot of contributing factors that lead to burnout. let us start by looking at work related issues that can contribute lack of control, Unclear job expectations, Dysfunctional workplace, Dynamics mismatch in values job, Fit and work life balance. There are also lifestyle issues, they can contribute to job burnout. You know that we try to leave our problems at home but that doesn't always work, and we walk into the office already stressed out. It can be more stress family or marital problems pre-existing conditions like alcoholism, drug dependency anxiety or depression lack of healthy diet and exercise or not getting enough sleep and finally there are personality traits. That can contribute to burnout perfectionist tendencies negative view of sell for world and high achieving personality type.

\section{EUSTRESS VS DISTRESS}

When we use the word stress, we're usually implying that stress is a purely negative thing but not all stress is the same to generalise. There are two different types of Distress and Eustress. Distress is stress that is not wanted because anxiety painful tensioner pressure strain and suffering. It is negative and detrimental to you. On the other hand, Eustress is that perceived positive or beneficial by the person experiencing it. EU stresses experienced is wanted for filling meaningful exciting and pleasurable tension or pressure. Eustress most commonly occurs, when we are facing a new challenge, but it is a challenge that is wanted. Eustress tends to occur when we feel we are adequate for the task and therefore confident and positively stimulated by that challenge. Rest tends to curve we feel overwhelmed because, we feel they were not adequate to the task. We like the necessary resources to meet demand therefore not confident eustress is necessary for personal growth. It is necessary for a sense of a fulfilment of happiness. Distress on the other hand is detrimental to health and wellbeing being so unique that all people have a different experience. When it comes to, what causes them Eustress versus Distress. This is especially the case when it comes to your purpose. You could consider you to be made for your purpose right otherwise what else are you doing on this earth. So, if you are made for a specific purpose, that also means you are made for specific types of stress now if we are experiencing a stress in the category of something that we are made for in other words experiencing a type of stress. We were made for then it is going to tend towards the category of eustress instead of distress.

\section{INDIVIDUAL DIFFERENCES THAT PROMOTE EUSTRESS}

when we are being forced to feel like being forced to do something or must do something. We do not want to do we naturally sit down to the distress category. We can change our perceptions about whatever it is that we are doing. We can decrease our level of distress. We can even think in a way or change our thoughts or perceptions in a way that we can turn things that are distressing into seeing them and your stressful way. We feel the stress instead of eustress. When we receive something to be a threat rather than challenge and we can change our perception that something is a threat. We can turn things into a welcome and positive challenge instead for being a tune to what causes stress. Naturally as opposed to taking something that currently 
causes you distress and trying to turn it into something that causes Eustress. It is really important element of our life finding. Our purpose going in the right direction. It is critical when it comes to understanding your intrinsic interests. It is also important to know the certain factors can determine, whether you perceive something is eustress versus distress.

\section{POSITIVITY}

Positive response thinking and eliminating sad thoughts and negative feelings. We have resentment towards others. Just having a crappy outlook on life those things force ourselves to not think those negative thoughts. we are forcing make us feel better. There is beauty all around. Our eyes are Luke can we see the sun shining great, can we hear the birds chirping great, can we feel the burns of the sun on our skin, its awesome simple beauty start feel happy. It starts with us. want to feel happy and positive short circuit test negative thoughts. We start to feel bad restart to find ourselves feeling guilty, feeling angry, feeling whatever, you feel is negative. Turn around force ourselves to think positively.

\section{OPTIMISM}

Frequently optimism pessimism is thought of a general dispositions or psychological states. Not deeply held philosophical positions global. Contacts optimist someone that looks on the bright side. Sees the glass half full Contacts do. This is taking to the extreme philosophical or like minutes in optimist believes. That we are living in the best of all possible works. In other words, the world as it is now logically as good as it could possibly be without a logical contradiction. Every other logically consistent possible world is worse than the actual world. we live in no matter how bad things seen for you it is a logical possibility them to Pierre about who is a making someone else is life even worse this may seem like a strange position.

\section{HOPE}

Hope is a good thing even the best thing and good thing never dies. It is a state of mind in which a person always be in a situation that the desire which he or she want will be fulfilled in any condition. It is a state of mind that directs that no matter what the situation will be everything will be going fine. It creates a unique energy and positivity which drove the human behaviour in a brighter way. Hope is alike of flowing water which always make the consistency of moving forward. It is one of the best tools to eliminate stress level and to increase the Eustress.

\section{SELF-ESTEEM SELF EFFICIENCY AND LOCUS OF CONTROL}

Self-esteem is the regard or respect that a person has for oneself. In self efficacy it is the belief in one's capabilities to organise and execute the courses of action required instant situations. So, in other words self-efficacy is a person's belief in his or her ability to succeed in a particular situation. So self-efficacy is much more specific and self-esteem, self-efficacy can have an impact on everything from psychological states to behaviour to motivation. In virtually all people can identify goals. They want to accomplish things, they want to change things, they want to achieve. However, most people also realize that putting these plans into action is not so simple. So, individuals of efficacy play a major role and how goals tasks and challenges are approached.

We can split self-efficacy up to two types of people with strong sense of self efficacy versus people with a weak sense of self efficacy. So, people with strong self of sense of self efficacy also developed deeper interest and activities in which they participate. They form a stronger sense of commitment to their interests and activities and they also recover quickly from setbacks and disappointments. There you have it they can recover quickly. They have strong interest their strong sense of commitment and they enjoy problems are challenging tasks. 
There are four major sources of self-efficacy. So, we look at these sources determine whether the person will have a strong or weak sense of self efficacy.

First is mastery of experiences so that means performing a task successfully will strengthen our sense of self efficacy. Then their social model sings people like our self successfully completed task raises are believes that we too have the capabilities to master comparable activities and also succeed the third source is social persuasion. Low self-esteem can have a high sense of self efficacy and vice versa. So, this is interesting perfectionist. Low self-esteem and possibly high sense of self efficacy and that is because they tend to be overly critical and negative about themselves.

Locus of control is the extent to which people perceive they have control over events in their lives. There are two types Internal and External locus of control.

Internal locus of control is when a person believes he or she can influence events in their outcomes. They attribute the results to their own trips. In a person with External locus of control blames outside forces for everything that review events. The viral mental traits or causes individuals of the high internal locus of control believe. That events in their life come primarily from their own actions. So, if a person with an internal locus of control does not perform as well as they wanted to on a test. Locus of control feel that they control their own destiny rather being largely to terminate by external forces, so they tend to be happier last past invest.

\section{DISCUSSION \& CONCLUSION}

It's important to know what causes burnout. So, you can address the root of the issue instead of getting bogged down with treating the symptoms. So, ask yourself why this is happening keep a Journal or diary compare, how you used to feel think act at work to how you feel think and act at work now. what is changed, what's happened once you identify the problem ask yourself is a work-related issue or is this a lifestyle or personality issue. If it is work related, then address it work a good place to start is with your supervisor. If your supervisor is part of the problem can you talk with another supervisor or someone in the human resources Department. If it is a lifestyle or personality issue where can you turn for support keeping your supervisor in the loop with what you are dealing with important. They might be able to direct you to additional resources such as your employee assistance program. No matter what the cause of the burnout support through this process is critical to your success depending on your situation. You might be able to get additional relief with some of the same techniques. You use for stress management, positive thinking, meditation, deep breathing, goal setting, take a vacation or days of healthy diet and exercise reconnect with your non work life. Since burnout is more severe than job stress. You may need additional techniques or even outside assistance from a qualified medical professional and keep in mind since burner takes a while to happen you cannot expect to go back to normal overnight.

\section{REFERENCES}

[1] Ainsworth, M. D. S., \& Bowlby, J. (1991). An ethological approach to personality. American Antonovsky, A. (1987). Unraveling the mysteries of health. San Francisco: Jossey-Bass.

[2] Antonovsky, A. (1993). The structure and properties of the sense of coherence scale. Social Science and Medicine, 36, 725-733.

[3] Artinian, B. M. (1997). Situational sense of coherence: Development and measurement of the construct. In B. M. Artinian \& M. M. Conger (Eds.), The intersystem model: Zntegrating theory and practice (pp. 18-30). Thousand Oaks, CA Sage.

[4] Barnett, R. C. (1998). Toward a review and reconceptualization of the worWfamily literature. Genetic, Social, and General Psychology Monographs, 124, 125-182. 
[5] Barnett, R. C., \& Marshall, N. L. (1992). Worker and mother roles, spillover effects, and psychological distress. Women \& Health, 18, 9-40.

[6] Barnett, R. C., Marshall, N. L., \& Sayer, A. (1992). Positive-spillover effects from job to home: A closer look. Women \& Health, 19, 13-41.

[7] Britt, T. W., Adler, A. B., \& Bartone, P. T. (2001). Deriving benefits from stressful events: The role of engagement in meaningful work and hardiness. Journal of Occupational Health Psychology, 6, 53-63.

[8] Cohen, S., \& Edwards, J. R. (1988). Personality characteristics as moderators ofthe relationship between stress and disorder. In W. J. Neufeld (Ed.), Advances in the investigation ofpsychological stress (pp. 235-283). New York: Wiley.

[9] DeFrank, R. S., \& Ivancevich, J. M. (1998). Stress on the job: An executive update. Academy of Management Executive, 12, 55-66.

[10] Development Of Small \& Medium Scale Enterprises: Protagonist Of Commercial Banks Funding. Dr. Saroj Kumar Ranjan Pooja Rawat, Bhanu Mati Doshi, Wesleyan Journal Of Research, Volume14, Issue (January 2021). Publisher-Bankura Christian College, Bankura, West Bengal, India.

[11] Edlin, G., Golanty, E., \& Brown, K. M. (1996). Health and wellness (5th ed.). Sudbury, MA: Jones and Bartlett.

[12] Edwards, J. R., \& Cooper, C. L. (1988). The impacts of positive psychological states on physical health: A review and theoretical framework. Social Science Medicine, 27( 12), 1147-1459.

[13] Estrada, C. A., Isen, A. M., \& Young, M. J. (1994). Positive affect improves creative problem solving and influences reported sources of practice satisfaction in physicians. Motivation and Emotion, 18, 285-299.

[14] Estrada, C. A., Isen, A. M., \& Young, M. J. (1997). Positive affect facilitates integration of information and decreases anchoring in reasoning among physicians. Organizational Behavior and Human Decision Processes, 72, 117-135.

[15] Farren, C. (1999). Stress and productivity: What tips the scale? Strategy and Leadership, Florian, V., Mikulincer, M., \& Taubman, 0. (1995). Does hardiness contribute to mental health during a stressful real-life situation? The roles of appraisal and coping. J o u $\mathrm{m} 1$ of Personality and Social Psychology, 68, 687-695. Psychologist, 46, 333-341. 27, 36 37. HEALTH PSYCHOLOGY AND WORK STRESS 117

[16] Folkman, S., \& Moskowitz, J. T. (2000). Positive affect and the other side of coping. American Ganster, D. C ., \& Schaubroeck, J. (1991). Work stress and employee health. Journal of Management, 17, 235-271. George, J. M., \& Brief, A. P. (1992). Feeling good-doing good: A conceptual analysis of mood at work-organizational spontaneity relationship. Psychological Bulletin, 112, 310-329.

[17] Gray-Toft, P., \& Anderson, J. G. (1981). Stress among hospital nursing staff: Its causes and effects. Social Science Medicine, 15, 639-647.

[18] Goswami, Tulsee Giri, and Saroj Kumar Ranjan. "Green HRM: Approach to Sustainability in Current Scenario." Journal for Studies in Management and Planning 1.4 (2015): 250-259.

[19] Hazan, C., \& Shaver, P. R. (1990). Love and work An attachment theoretical perspective. Journal of Personality and Social Psychology, 52, 511-524.

[20] Huy, Q. N. (1999). Emotional capability, emotional intelligence, and radical change. Academy of Management Review, 24, 325-345.

[21] Isen, A. M., Rosenzweig, A. S., \& Young, M. J. (1991). The influence of positive affect on clinical problem solving. Medical Decision Making, 11, 221-227. 
[22] Kahn, R. L., Wolfe, R. P., Quinn, R. P., Snoek, J. D., \& Rosenthal, R. A. (1964). Organizational stress: Studies in role conflict and ambiguity. New York Wiley.

[23] Karasek, R. A. (1979). Job demands, job decision latitude, and mental strain: Implications for job redesign. Administrative Science Quarterly, 24, 285-308.

[24] Kobasa, S. C. (1979). Stressful life events, personality, and health An inquiry into hardiness. Journal of Personality and Social Psychology, 37, 1-11.

[25] Kobasa, S. C., Maddi, S. R., \& Kahn, S. (1982). Hardiness and health A prospective study. Journal of Personality and Social Psychology, 42, 168-177.

[26] Lazarus, R. S. (1993). From psychological stress to the emotions: A history of changing outlooks. In L. W. Porter \& M. R. Rosenzweig (Eds.), Annual Review of Psychology (Vol. 44, pp. 1-21). Palo Alto, CA Annual Reviews.

[27] Lazarus, R. S., DeLongis, A., Folkman, S., \& Gruen, R. (1985). Stress and adaptational outcomes: The problem of confounded measures. American Psychologist, 40, 770-779. Lazarus, R. S., \& Folkman, S. (1984). Stress, appraisal and coping. New York: Springer.

[28] Lefcourt, H. M., \& Davidson-Katz, K. (1991). Locus of control and health. In C. R. Snyder \& D. R. Forsyth (Eds.), Handbook of social and clinical psychology (pp. 246-266). New York Pergamon Press.

[29] Maddi, S. (1998). Hardiness in health and effectiveness. In H. S. Friedman (Ed.), Encyclopaedia of mental health (Vol. 2, pp. 323-335). San Diego, CA Academic Press. McCrae, R. R., \& Costa, P. T., Jr. (1994). The stability of personality: Observations and evaluations. Current Directions in Psychological Science, 3, 173-175.

[30] Mishra, A. K., \& Spreitzer, G. M. (1998). Explaining how survivors respond to downsizing: The roles of trust, empowerment, justice, and work redesign. Academy of Management Review, 23, 567-588.

[31] Mittal, V., \& Ross, W. T., Jr. (1998). The impact of positive and negative affect and issue framing on issue interpretation and risk taking. Organizational Behavior and Human Decision Processes, 76, 298-324.

[32] Saroj Kumar Ranjan. "Psychological contract breach and workplace outcome: unmet expectations of an employee". Journal for Studies in Management and Planning. Vol-04, Issue04, April-2018, ISSN: 2395-0463.

[33] Saroj Kumar Ranjan*, Dr.Tulsee Giri Goswami**," Psychological Contract Breach and Workplace Outcome: Effective Relationship among Employee and Organization.” Think India Journal ISSN: 0971-1260, Vol-22, Special Issue-15 Entrepreneurship, and Management: Challenges, Issues, and Opportunities in the Global Economy. 